Research Article

\title{
Strength Characteristics and Slope Stability of Expansive Soil from Pingdingshan, China
}

\author{
Ju-yun Zhai $\circledast^{1}{ }^{1}$ and Xiang-yong Cai ${ }^{2}$ \\ ${ }^{1}$ Henan University of Urban Construction, Pingdingshan, Henan, China \\ ${ }^{2}$ Pingdingshan Government Water Saving Management Office, Pingdingshan, Henan, China
}

Correspondence should be addressed to Ju-yun Zhai; 331626242@qq.com

Received 10 November 2017; Accepted 25 December 2017; Published 25 February 2018

Academic Editor: João M. P. Q. Delgado

Copyright (C) 2018 Ju-yun Zhai and Xiang-yong Cai. This is an open access article distributed under the Creative Commons Attribution License, which permits unrestricted use, distribution, and reproduction in any medium, provided the original work is properly cited.

\begin{abstract}
By analyzing the characteristics of expansive soil from Pingdingshan, China, the shear strength parameters at different water contents, dry densities, and dry-wet cycles of expansive soil are obtained. It is found that, at higher soil-water content, the internal friction angle is $0^{\circ}$ and the shallow layer of expansive soil slope will collapse and destroy; this has nothing to do with the height of the slope and the size of the slope. The parameters of soil influenced by atmosphere are the ones which have gone through dry-wet cycles, and the parameters of soil without atmospheric influence are the same as those of natural soil. In the analysis of slope stability, the shear strength parameters of soil can be determined by using the finite element method, and the stability coefficient of the expansive soil slope can be calculated.
\end{abstract}

\section{Introduction}

Disasters, such as deformation and destruction, occur to natural slopes, roads, mounds, foundation pits, and artificial slopes of underground engineering excavation, resulting in great economic losses [1]. Especially, a series of disasters, such as crack, landslide, and slump, are more apt to occur to expansive soil because of the water sensitivity [2-4]. The strength of expansive soil slope shallow layers is greatly affected by climatic conditions [5-7]. The study on the strength and slope stability of expansive soil is of great significance to control and prevent the natural disasters [8-10].

Much work has been done on the expansive soils. Experimental study on drying and wetting cycles of undisturbed expansive soil in Nanning area has been done in [11]. Tang and Shi studied the deformation on drying and wetting cycles of the pukou area in nanjing [12]. Wei and Wang studied the expansion and shrinkage deformation mechanism of solidified expansive soil [13]. Zhai et al. studied the permeability and intensity characteristics of expansive soil from Pingdingshan [14]. There are few reports on the stability of the Pingdingshan expansive soil slope under the influence of the atmosphere.

This paper simulates the effects of the atmosphere. Based on the analysis of the different water contents, dry densities and strength characteristics of the expansive soil in Pingdingshan, the stability of the Pingdingshan expansive soil slope under the influence of the atmosphere is studied. It could provide a reference for engineering design.

\section{Brief Introduction to Expansive Soil from Pingdingshan}

The expansive soil from Pingdingshan is meanly montmorillonite. The humidity coefficient is $0.7-0.8$, the depth of atmospheric influence is generally $<4 \mathrm{~m}$, and the sharp depth of the atmospheric influence is $1.5 \sim 1.8 \mathrm{~m}$. Parameters of natural soil samples that have been tested are as follows: natural water content of $20 \% \sim 26 \%$, natural density of $1.8 \sim 2.0 \mathrm{~g} / \mathrm{cm}^{3}$, dry density of $1.5 \sim 1.7 \mathrm{~g} / \mathrm{cm}^{3}$, pore ratio of $0.69 \sim 0.81$, compression index of $0.08 \sim 0.15$, cohesive force of $35 \sim 85 \mathrm{kPa}$, internal friction angle of $9 \sim 27^{\circ}$, and free expansion rate of 51-71. 
TABle 1: Pingdingshan expansive soil chemical composition and content.

\begin{tabular}{|c|c|}
\hline Constituent & Content (\%) \\
\hline $\mathrm{SiO}_{2}$ & 53.26 \\
\hline $\mathrm{CaO}$ & 11.02 \\
\hline $\mathrm{Al}_{2} \mathrm{O}_{3}$ & 3.46 \\
\hline $\mathrm{MgO}$ & 0.416 \\
\hline $\mathrm{P}_{2} \mathrm{O}_{5}$ & 0.166 \\
\hline $\mathrm{Fe}_{2} \mathrm{O}_{3}$ & 20.37 \\
\hline $\mathrm{CuO}$ & 1.275 \\
\hline $\mathrm{K}_{2} \mathrm{O}$ & 0.840 \\
\hline $\mathrm{TiO}_{2}$ & 0.216 \\
\hline $\mathrm{SO}_{3}$ & 0.131 \\
\hline $\mathrm{MnO}$ & 0.0979 \\
\hline $\mathrm{ZnO}$ & 0.0575 \\
\hline $\mathrm{SrO}$ & 0.005 \\
\hline $\mathrm{Tb}_{4} \mathrm{O}_{7}$ & 0.002 \\
\hline Compton & 0.866 \\
\hline $\mathrm{Na}_{2} \mathrm{O}$ & 0.059 \\
\hline $\mathrm{PbO}$ & 0.0403 \\
\hline $\mathrm{ZrO}_{2}$ & 0.004 \\
\hline Rayleigh & 74.5 \\
\hline
\end{tabular}

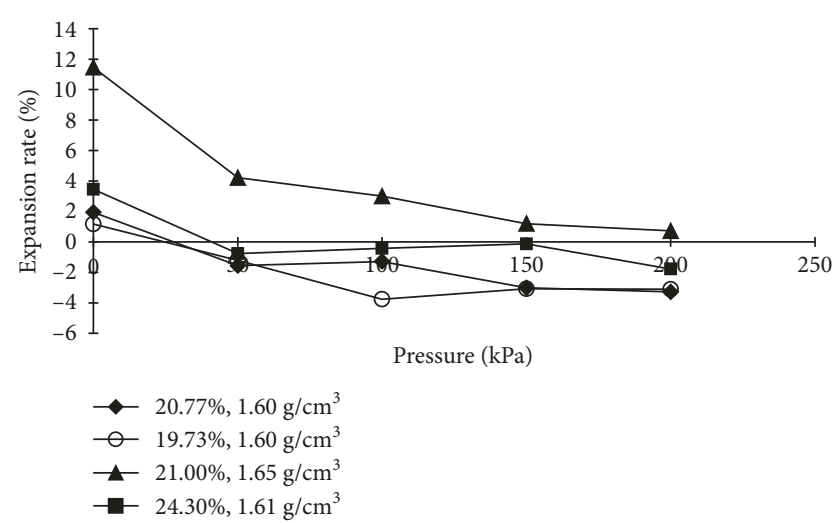

Figure 1: Dependence of the expansion on the vertical pressure.

\section{The Characteristics of the Expansive Soil from Pingdingshan}

3.1. The Selection of Expansive Soil Samples. The disturbed soil samples of expansive soil taken for experiment are at the intersection of the construction road and the Dongfeng road in Pingdingshan city. Through the indoor soil test, the plastic limit of the expansive soil is $22.85 \%$, the $17 \mathrm{~mm}$ liquid limit is $45.72 \%$, and the free expansion rate is $55 \%$. The chemical composition and content of expansive soil are shown in Table 1.

3.2. Deformation Parameters of Expansive Soil. To the representative expansion soil which was air-dried, grounded, and sieved by a $2 \mathrm{~mm}$ sieve was added appropriate amount of water, stirred evenly, and was finally made into remolding

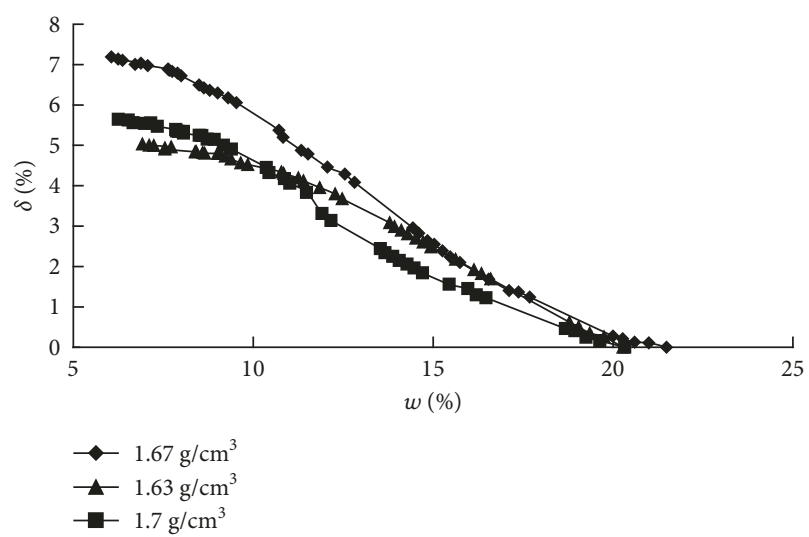

Figure 2: Dependence of the shrinkage on the water content A.

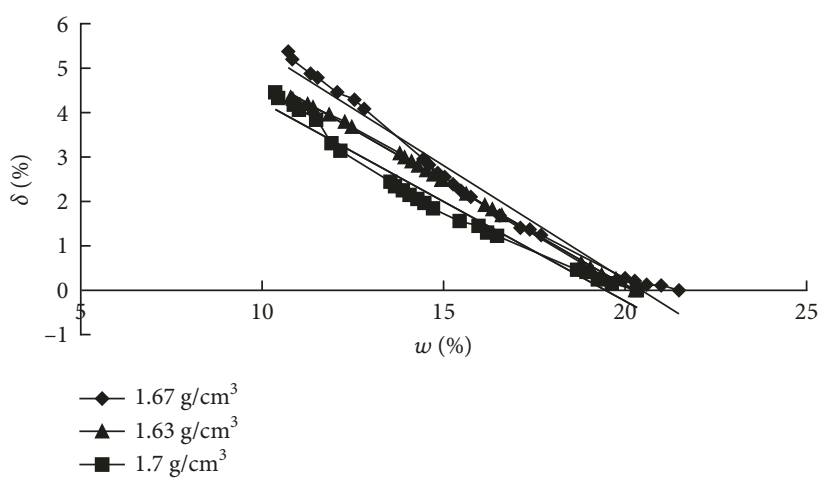

Figure 3: Dependence of the shrinkage on the water content B.

soil samples of different water contents and dry densities. After compaction, the diameter of the samples is $61.8 \mathrm{~mm}$ and the height is $20 \mathrm{~mm}$. Furthermore, by studying the expansion-shrinkage deformation, the deformation parameters were obtained. The relation curves of the expansion rate with vertical pressure are shown in Figure 1.

The relation curves of the shrinkage rate with water content were obtained by shrinkage test at three different dry densities of expansive soils, as shown in Figure 2.

The straight line of Figure 2 is fitted with a straight-line equation, as shown in Figure 3.

The following can be found:

The dry density: $1.67 \mathrm{~g} / \mathrm{cm}^{3}$; the water content: $21 \%$; the fitting equation: $y=-0.5144 x+10.522$; and $R^{2}=0.977$. The dry density: $1.63 \mathrm{~g} / \mathrm{cm}^{3}$; the water content: $21 \%$; the fitting equation: $y=-0.4692 x+9.4898$; and $R^{2}=0.999$. The dry density: $1.70 \mathrm{~g} / \mathrm{cm}^{3}$; the water content: $20 \%$; the fitting equation: $y=-0.4474 x+8.7071$; and $R^{2}=0.9688$.

3.3. Strength Characteristics of Expansive Soils. The representative expansive soil that was sieved by a $2 \mathrm{~mm}$ sieve was made into a sample of dry soil with the dry density of $1.5 \mathrm{~g} / \mathrm{cm}^{3}$ and $1.6 \mathrm{~g} / \mathrm{cm}^{3}$ and water content of $30 \%, 31 \%$, and $33 \%$. The shear strength curve could be obtained through direct shear test at room temperature as shown in Figure 4. 


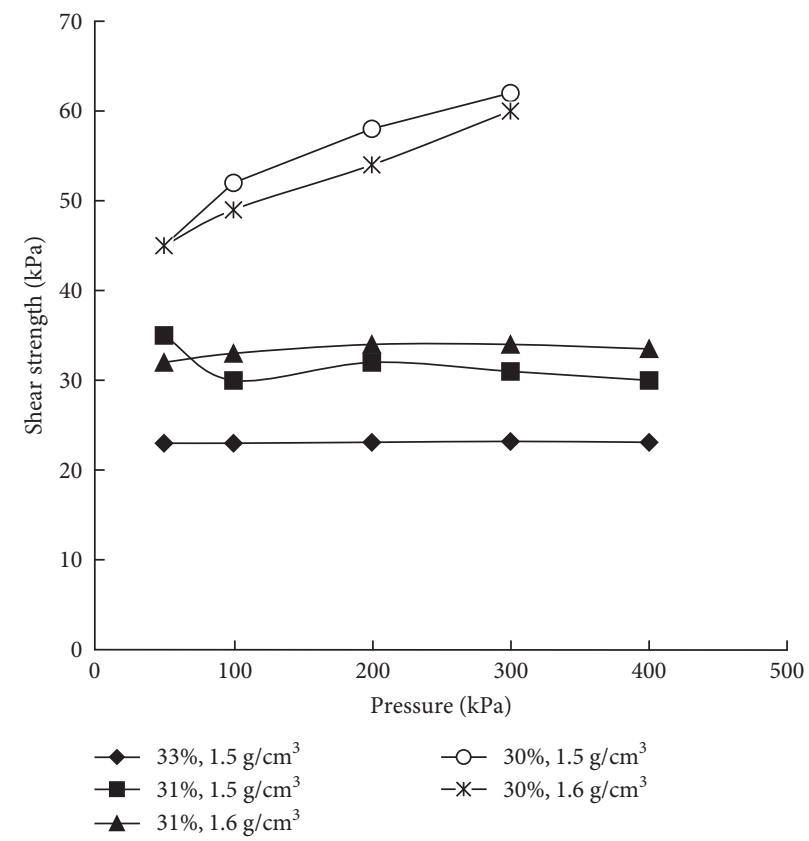

FIGURE 4: Shear strength-pressure curves at 33\%, 31\%, and 30\% water contents.

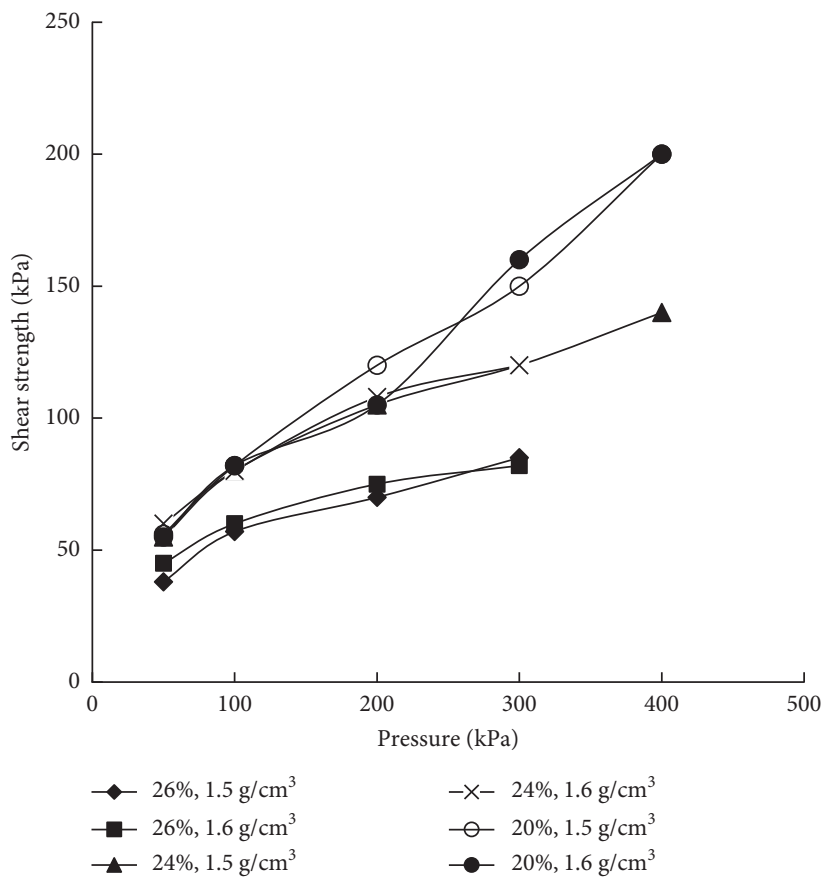

Figure 5: Shear strength-pressure curves at 26\%,24\%, and 20\% water contents.

The shear strength of the expansive soil under a high water contentunder the same pressure decreases significantly with the increase of water content (Figure 4 ). And the internal friction angle decreases to 0 , when the water content increases over a certain degree. Meanwhile, the value of cohesion decreases significantly with the increase in water content. The collapse of slope is unconcerned about slope height and slope foot size, on a heavy rainfall condition.
Therefore, the effective measure of slope protection is to handle slope waterproofing and drainage well.

The shearing testing of the expansive soil of water content of $26 \%, 24 \%, 20 \%$, dry density of $1.5 \mathrm{~g} / \mathrm{m}^{3}, 1.6 \mathrm{~g} / \mathrm{m}^{3}$ is carried out. The curve is shown in Figure 5.

The internal friction angle of the expansive soil decreases with the increase of water content, under a low water content. And the shear strength changed with the density of 
TABLE 2: Shear strength parameters of expansive soil at the dry density of $1.5 \mathrm{~g} / \mathrm{cm}^{3}$.

\begin{tabular}{lcc}
\hline Water content (\%) & $\begin{array}{c}\text { Angle of internal } \\
\text { friction }\left(^{\circ}\right)\end{array}$ & Cohesive force $(\mathrm{kPa})$ \\
\hline 19.11 & 25.0 & 44.0 \\
20.00 & 21.7 & 46.0 \\
21.12 & 18.0 & 58.0 \\
24.00 & 13.0 & 61.2 \\
25.00 & 10.0 & 50.0 \\
26.00 & 9.5 & 43.2 \\
30.00 & 4.0 & 45.1 \\
31.00 & 0.0 & 33.51 \\
33.00 & 0.0 & 24.16 \\
\hline
\end{tabular}

TABLE 3: Shear strength parameters of expansive soil at the dry density of $1.6 \mathrm{~g} / \mathrm{cm}^{3}$.

\begin{tabular}{lcc}
\hline Water content (\%) & $\begin{array}{c}\text { Angle of internal } \\
\text { friction }\left({ }^{\circ}\right)\end{array}$ & Cohesive force $(\mathrm{kPa})$ \\
\hline 19.11 & 28.0 & 36.0 \\
20.00 & 23.4 & 37.0 \\
21.12 & 16.1 & 68.0 \\
24.00 & 12.2 & 67.2 \\
25.00 & 8.1 & 58.0 \\
26.00 & 6.4 & 55.7 \\
30.00 & 3.6 & 43.2 \\
31.00 & 0.0 & 34.2 \\
33.00 & 0.0 & 24.2 \\
\hline
\end{tabular}

soil obscurely, when the water content of soil is the same, as shown in Figure 5.

The equation of soil shear strength is

$$
\tau_{f}=\tan \varphi \cdot \sigma+C
$$

where $\tau_{f}$ is the shear strength $(\mathrm{kPa}), \varphi$ is the angle of internal friction $\left({ }^{\circ}\right)$, and $C$ is the cohesive force $(\mathrm{kPa})$.

Comparing the shear strength curve fitting equation of multiple water content, the shear strength characteristics of the expansive soil at the dry density of $1.5 \mathrm{~g} / \mathrm{cm}^{3}$ are shown in Table 2 .

The shear strength characteristics of the expansive soil at the dry density of $1.6 \mathrm{~g} / \mathrm{cm}^{3}$ are shown in Table 3:

3.4. The Characteristics of Expansive Soil during Drying and Wetting Cycles. Samples of Pingdingshan expansive soil were remolded, and the attenuation law of shear strength after drying and wetting cycles was studied in the test. The shear strength sharply reduced in the first $2 \sim 4$ cycles and then tended to be stable. The stable strength parameters should be taken during the construction of the project.

Take the expansive soil sample with initial water content of $24 \%$ as an example. The soil sample passes through 1, 2, 3, 4 , and 5 times dry-wet cycles. The water content ranges from

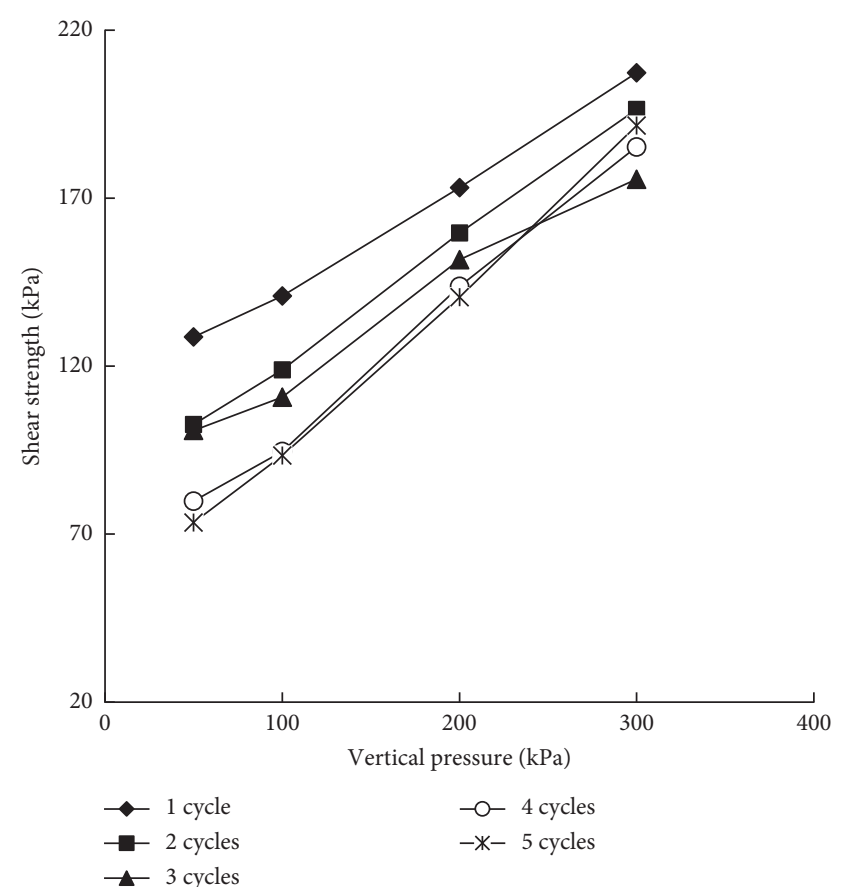

FIgURE 6: Dependence of shear strength under dry-wet cycles on the vertical pressure.

TABLE 4: The parameters of stable shear strength when the control water content is $25 \%$.

\begin{tabular}{lcc}
\hline $\begin{array}{l}\text { Water content variation } \\
\text { range }(\%)\end{array}$ & $\begin{array}{c}\text { Angle of internal } \\
\text { friction }\left(^{\circ}\right)\end{array}$ & $\begin{array}{c}\text { Cohesive force } \\
(\mathrm{kPa})\end{array}$ \\
\hline $32.0 \sim 13.3$ & 9.2 & 20.6 \\
$32.0 \sim 17.6$ & 7.5 & 44.8 \\
$32.0 \sim 25.0$ & 8.3 & 35.9 \\
$29.6 \sim 15.0$ & 7.5 & 40.0 \\
$29.6 \sim 16.8$ & 9.7 & 38.4 \\
$29.6 \sim 18.5$ & 10.3 & 44.3 \\
$27.4 \sim 16.0$ & 10.1 & 39.9 \\
$27.4 \sim 17.3$ & 11.5 & 45.3 \\
$27.4 \sim 18.2$ & 13.3 & 40.5 \\
\hline
\end{tabular}

$24.0 \%$ to $16.6 \%$. And then, samples of the same water content was made, which is called the control of water content. The characteristic curve of the shear strength of $20 \%$ is shown in Figure 6.

In the same way, by testing the expansive soil shear strength of other water contents under dry-wet cycles, the shear strength of the control water contents $20 \%$ and $25 \%$ is obtained. With the linear fitting of expansive soil stable strength, the strength parameters are obtained, as shown in Tables 4 and 5 .

\section{Calculation of Slope Stability of Expansive Soil}

4.1. The Selection of the Computational Model. The stability calculation of the expansive soil slope is based on the 
TABLE 5: The parameters of stable shear strength when the control water content is $20 \%$.

\begin{tabular}{lcc}
\hline $\begin{array}{l}\text { Water content variation } \\
\text { range (\%) }\end{array}$ & $\begin{array}{c}\text { Angle of internal } \\
\text { friction }\left({ }^{\circ}\right)\end{array}$ & $\begin{array}{c}\text { Cohesive force } \\
(\mathrm{kPa})\end{array}$ \\
\hline $28.0 \sim 16.1$ & 22.5 & 49.6 \\
$28.0 \sim 16.9$ & 23.7 & 55.1 \\
$28.0 \sim 18.7$ & 36.5 & 72.8 \\
$26.0 \sim 13.6$ & 25.5 & 19.9 \\
$26.0 \sim 15.8$ & 26.0 & 53.376 \\
$26.0 \sim 17.6$ & 24.0 & 54.2 \\
$24.0 \sim 11.8$ & 25.3 & 45.4 \\
$24.0 \sim 15.1$ & 26.5 & 58.0 \\
$24.0 \sim 16.6$ & 22.5 & 57.0 \\
\hline
\end{tabular}

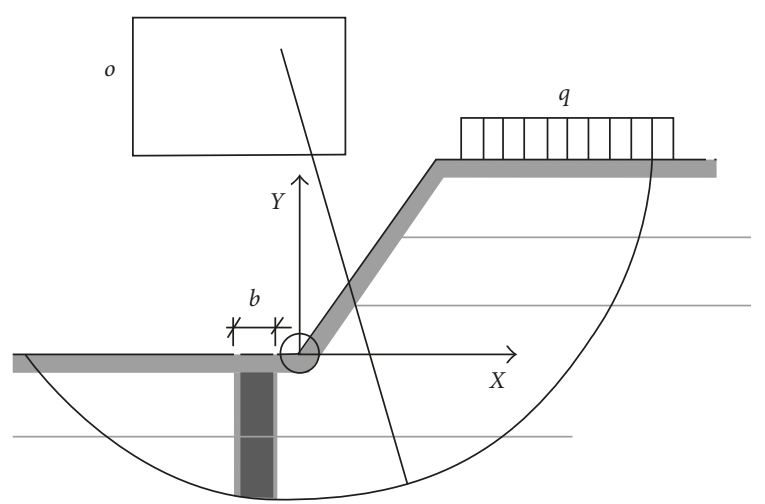

Figure 7: The position of the most unfavorable center.

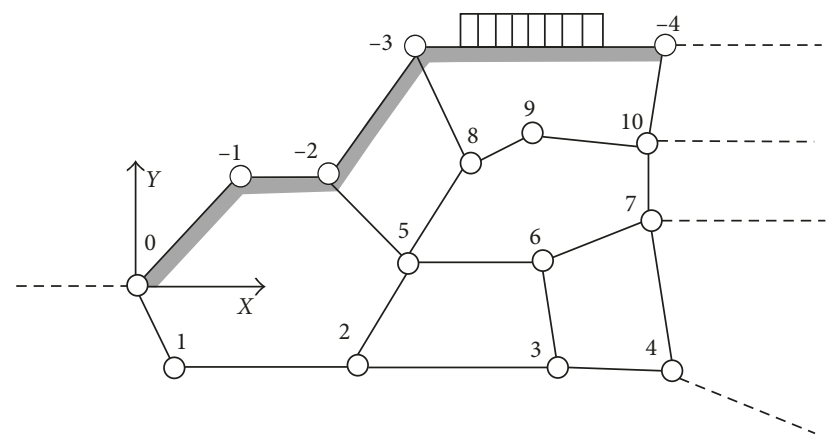

FIGURE 8: Segmentation position of the slope soil unit.

Swedish method. The safety factor could be calculated, and the position of the most unfavorable center could be searched by Lizheng software, as shown in Figure 7. In the figure, $b=1 \mathrm{~m}$ is the width of the earth bar and $q=30 \mathrm{kPa}$ is the overload size.

Shear strength parameters of slope soil are different at different positions. The slope is divided into multiple units, as shown in Figure 8.

In the shallow layer of the soil, the shear strength parameters within $2 \mathrm{~m}$ from the soil surface are the same as
TABLE 6: The calculation coordinates of each node with the vertical projection of $6 \mathrm{~m}$.

\begin{tabular}{lcccccccccc}
\hline Node label & 0 & -1 & -2 & 1 & 2 & 3 & 4 & 5 & 6 & 7 \\
\hline$X$ coordinate & 0 & 6 & 16 & -6 & 9 & 8 & 20 & 15 & 25 & -8 \\
$Y$ coordinate & 0 & 6 & 6 & -5 & -6 & 2 & -6 & 3 & 5 & 0 \\
\hline
\end{tabular}

TABLE 7: The slope safety factor and the most unfavorable center position with the horizontal projection of $10 \mathrm{~m}$.

\begin{tabular}{lccccc}
\hline $\begin{array}{l}\text { Serial } \\
\text { number }\end{array}$ & $\begin{array}{c}\text { Slope } \\
\text { height } \\
(\mathrm{m})\end{array}$ & $\begin{array}{c}\text { Slope } \\
\text { angle }\left({ }^{\circ}\right)\end{array}$ & $\begin{array}{c}\text { The most } \\
\text { unfavorable } \\
\text { center }(\mathrm{m})\end{array}$ & $\begin{array}{c}\text { Radius } \\
(\mathrm{m})\end{array}$ & $\begin{array}{c}\text { Safety } \\
\text { factor }\end{array}$ \\
\hline 1 & 8 & 38.7 & $(4.267,10.133)$ & 15.82 & 1.79 \\
2 & 10 & 45.0 & $(1.000,18.000)$ & 18.03 & 1.52 \\
3 & 11 & 47.7 & $(0.000,18.700)$ & 18.70 & 1.37 \\
4 & 12 & 50.2 & $(0.000,19.200)$ & 19.20 & 1.25 \\
5 & 15 & 56.3 & $(-3.000,22.000)$ & 22.20 & 1.01 \\
\hline
\end{tabular}

TABLE 8: The safety factor and radius at the slope height of $6 \mathrm{~m}$.

\begin{tabular}{lccccc}
\hline $\begin{array}{l}\text { Serial } \\
\text { number }\end{array}$ & $\begin{array}{c}\text { Horizontal } \\
\text { projection } \\
(\mathrm{m})\end{array}$ & $\begin{array}{c}\text { Slope } \\
\text { angle }\left({ }^{\circ}\right)\end{array}$ & $\begin{array}{c}\text { The most } \\
\text { unfavorable } \\
\text { center }(\mathrm{m})\end{array}$ & $\begin{array}{c}\text { Radius } \\
(\mathrm{m})\end{array}$ & $\begin{array}{c}\text { Safety } \\
\text { factor }\end{array}$ \\
\hline 1 & 6 & 45.0 & $(2.400,9.600)$ & 9.89 & 2.08 \\
2 & 5 & 50.2 & $(1.200,10.800)$ & 10.87 & 1.96 \\
3 & 4 & 56.3 & $(1.200,10.800)$ & 10.87 & 1.95 \\
4 & 3 & 63.4 & $(0.000,9.600)$ & 9.60 & 1.73 \\
5 & 2 & 71.6 & $(-2.400,10.800)$ & 11.10 & 1.58 \\
6 & 1 & 80.5 & $(-3.300,9.600)$ & 10.15 & 1.43 \\
7 & 0 & 90.0 & $(-3.000,0.000)$ & 8.75 & 1.35 \\
\hline
\end{tabular}

those after dry-wet cycles. The shear strength parameters deeper than $2 \mathrm{~m}$ are the same as those of the initial soil.

4.2. Calculation of Slope Safety Factor. The horizontal projection of the expansive soil slope is $10 \mathrm{~m}$ and the vertical projection is $6 \mathrm{~m}$. The coordinates of each node calculation unit are shown in Table 6.

Soil slopes are divided into multiple areas by the nodes. The density of the soil is $20 \mathrm{kN} / \mathrm{m}^{3}$. The water content of each area is determined by the indoor tests. The shear strength parameters of shallow soil are the stable parameters, which after the dry-wet cycles are $C=40 \mathrm{kPa}$ and $\varphi=11^{\circ}$. The parameters of inner area are the same as natural soil strength parameters: $C=40 \mathrm{kPa}$ and $\varphi=17^{\circ}$.

With the horizontal projection of $10 \mathrm{~m}$, the slope safety factor and the most unfavorable center position at different slope heights are calculated by the Lizheng software, as shown in Table 7. 
TABLE 9: The safety factor and radius at the slope height of $8 \mathrm{~m}$.

\begin{tabular}{lccccc}
\hline Serial number & Horizontal projection $(\mathrm{m})$ & Slope angle $\left(^{\circ}\right)$ & The most unfavorable center $(\mathrm{m})$ & Radius $(\mathrm{m})$ & Safety factor \\
\hline 1 & 9 & 41.6 & $(3.200,12.800)$ & 13.19 & 1.82 \\
2 & 8 & 45.0 & $(2.133,12.800)$ & 1.74 \\
3 & 7 & 48.8 & $(1.067,12.800)$ & 12.98 & 1.65 \\
4 & 6 & 53.1 & $(0.000,14.400)$ & 14.40 & 1.57 \\
5 & 5 & 58.0 & $(0.000,12.800)$ & 1.50 \\
6 & 4 & 63.4 & $(-2.800,14.400)$ & 14.67 \\
7 & 3 & 69.4 & $(-2.600,12.800)$ & 1.41 \\
8 & 2 & 76.0 & $(-7.700,14.400)$ & 1.06 & 17.54 \\
9 & 1 & $(-6.000,11.200)$ & 1.33 \\
10 & 0 & 90.9 & & 1.22 \\
\hline
\end{tabular}

TABLE 10: The safety factor and radius at the slope height of $9 \mathrm{~m}$.

\begin{tabular}{|c|c|c|c|c|c|}
\hline Serial number & Horizontal projection $(\mathrm{m})$ & Slope angle $\left({ }^{\circ}\right)$ & The most unfavorable center $(\mathrm{m})$ & Radius $(\mathrm{m})$ & Safety factor \\
\hline 1 & 10 & 43.0 & $(2.057,16.200)$ & 16.33 & 1.70 \\
\hline 2 & 9 & 45.0 & $(1.030,16.200)$ & 16.23 & 1.62 \\
\hline 3 & 8 & 48.4 & $(0.000,16.200)$ & 16.20 & 1.54 \\
\hline 4 & 7 & 52.1 & $(0.000,16.200)$ & 16.20 & 1.47 \\
\hline 5 & 6 & 56.3 & $(0.000,14.400)$ & 14.40 & 1.41 \\
\hline 6 & 5 & 61.0 & $(-2.000,16.200)$ & 16.32 & 1.34 \\
\hline 7 & 4 & 66.0 & $(-4.200,16.200)$ & 16.74 & 1.27 \\
\hline 8 & 3 & 71.6 & $(-6.500,18.000)$ & 19.14 & 1.19 \\
\hline 9 & 2 & 77.5 & $(-8.400,18.000)$ & 19.86 & 1.11 \\
\hline 10 & 1 & 83.7 & $(-9.900,18.00)$ & 20.54 & 1.03 \\
\hline 11 & 0 & 90.0 & $(-9.000,14.400)$ & 16.81 & 0.97 \\
\hline
\end{tabular}

TABLE 11: The safety factor and radius at the slope height of $10 \mathrm{~m}$.

\begin{tabular}{|c|c|c|c|c|c|}
\hline Serial number & Horizontal projection $(\mathrm{m})$ & Slope angle $\left({ }^{\circ}\right)$ & The most unfavorable center $(\mathrm{m})$ & Radius (m) & Safety factor \\
\hline 1 & 10 & 45.0 & $(1.000,18.000)$ & 18.03 & 1.52 \\
\hline 2 & 8 & 51.3 & $(0.000,17.000)$ & 17.00 & 1.38 \\
\hline 3 & 7 & 55.0 & $(0.000,16.000)$ & 16.00 & 1.32 \\
\hline 4 & 6 & 59.0 & $(-2.130,17.000)$ & 17.13 & 1.27 \\
\hline 5 & 5 & 63.4 & $(-3.000,17.000)$ & 17.26 & 2.21 \\
\hline 6 & 4 & 68.2 & $(-5.600,8.000)$ & 18.82 & 1.15 \\
\hline 7 & 3 & 73.3 & $(-6.500,17.000)$ & 18.20 & 1.08 \\
\hline 8 & 2 & 78.7 & $(-10.800,20.000)$ & 22.73 & 1.02 \\
\hline 9 & 1 & 84.3 & $(-13.200,20.000)$ & 23.96 & 0.94 \\
\hline 10 & 0 & 90.0 & $(-11.000,17.000)$ & 20.10 & 0.90 \\
\hline
\end{tabular}

Similarly, the safety factor and the radius at the slope heights of $6 \mathrm{~m}, 8 \mathrm{~m}, 9 \mathrm{~m}$, and $10 \mathrm{~m}$ are calculated, as shown in Tables 8-11.

4.3. Analysis of Safety Factor of Expansive Soil at Different Slope Heights. The safety factor at different slope heights of $6 \mathrm{~m}, 8 \mathrm{~m}, 9 \mathrm{~m}$, and $10 \mathrm{~m}$, with the abscissa of level projection and the ordinate of safety factor, is shown in Figure 9.

\section{Conclusion}

In this paper, the physical and mechanical characteristics of expansive soils from Pingdingshan are analyzed, which provide a reliable basis for engineering design and they can be used in the calculation of slope stability. The finite element method is used to calculate the different positions of the soil slope layers and select the corresponding strength parameters. 


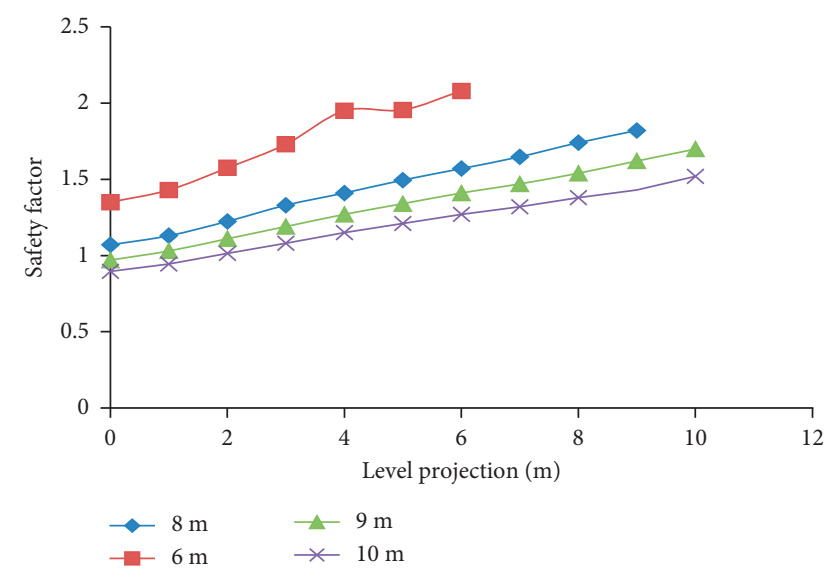

FIGURE 9: Change in slope safety factor with slope level projection.

\section{Conflicts of Interest}

No potential conflicts of interest were reported by the authors.

\section{Acknowledgments}

This research was supported by the Science and Technology Planning Project of Henan (no. 152192310091), the Innovation Talent Project of Pingdingshan (no. 2017010(10.3)), and the Key Scientific Research Projects in Henan colleges and universities (no. 18B560001).

\section{References}

[1] D. Zhou, Y.-G. Sun, G.-Y. Le et al., "Model test of the influence of environmental factors on temperature field in expansive soil slope," Journal of Guangxi University, vol. 36, no. 4, pp. 653-658, 2011.

[2] L.-T. Zhan, "Study on soil-water interaction in unsaturated expansive soil slops," Journal of Zhejiang University, vol. 40, no. 3, pp. 496-497, 2006.

[3] T.-H. Liu, Expansive Soil Problem of Construction, China Architecture \& Building Press, Beijing, China, 1997.

[4] Y. Xie, Z.-H. Chen, and G. Li, "Research of thermal effects on shear strength and deformation characteristics of unsaturated bentonite soils," Chinese Journal of Geotechnical Engineering, vol. 27, no. 9, pp. 1082-1085, 2005.

[5] B. D. De and J. F. Thimus, "The influence of temperature on mechanical characteristics of boom clay: the results of an initial laboratory programme," Engineering Geology, vol. 41, pp. 17-126, 1996.

[6] Y.-X. Gao, Z. Feng, and J.-L. Zheng, "Temperature properties of sheer strength for unsaturated soil," Journal of Changsha Communications University, vol. 18, no. 4, pp. 68-71, 2002.

[7] J.-H. Wu, J.-P. Yuan, L.-J. He, and T.-H. Lu, "Study on distribution and change laws of soil water content due to evaporation," Journal of Disaster Prevention and Mitigation Engineering, vol. 3, no. 3, pp. 290-294, 2013.

[8] Y. Zheng, W. Ma, and H. Bing, "Impact of freezing and thawing cycles on the structures of soil and a quantitative approach," Journal of Glaciology and Geocryology, vol. 37, no. 1, pp. 132-137, 2015.
[9] S. A. B. Mrabent, A. Hachichi, H. Souli, S. Taibi, and J.-M. Fleureau, "Effect of lime on some physical parameters of a natural expansive clay from Algeria," European Journal of Environmental and Civil Engineering, vol. 21, no. 1, pp. 108125, 2017.

[10] A. Boukelia, H. Eslami, S. Rosin-Paumier, and F. Masrouri, "Effect of temperature and initial state on variation of thermal parameters of fine compacted soils," European Journal of Environmental and Civil Engineering, pp. 1-14, 2017.

[11] H.-B. Lv, Z.-T. Zeng, Y.-L. Zhao, and H. Lu, "Experimental studies of strength of expansive soil in drying and wetting cycles," Rock and Soil Mechanics, vol. 30, no. 12, pp. 37973802, 2009

[12] C.-S. Tang and B. Shi, "Swelling and shrinkage behaviour of expansive soil during wetting-drying cycles," Chinese Journal of Geotechnical Engineering, vol. 33, no. 9, pp. 1376-1383, 2011.

[13] X. Wei and G. Wang, "Modeling swell-shrink behavior of compacted expansive clays subjected to cyclic drying and wetting," Chinese Journal of Geotechnical Engineering, vol. 36, no. 8, pp. 1423-1431, 2014.

[14] J.-Y. Zhai, X. Hao, G.-X. Wei et al., "Strength characteristics of expansive soil during drying and wetting cycles," Electronic Journal of Geotechnical Engineering, vol. 22, no. 12, pp. 4579-4588, 2017. 


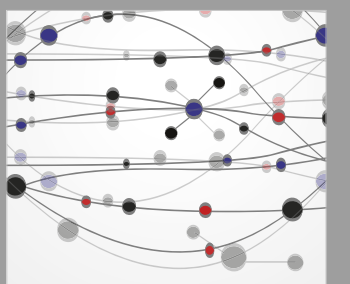

The Scientific World Journal
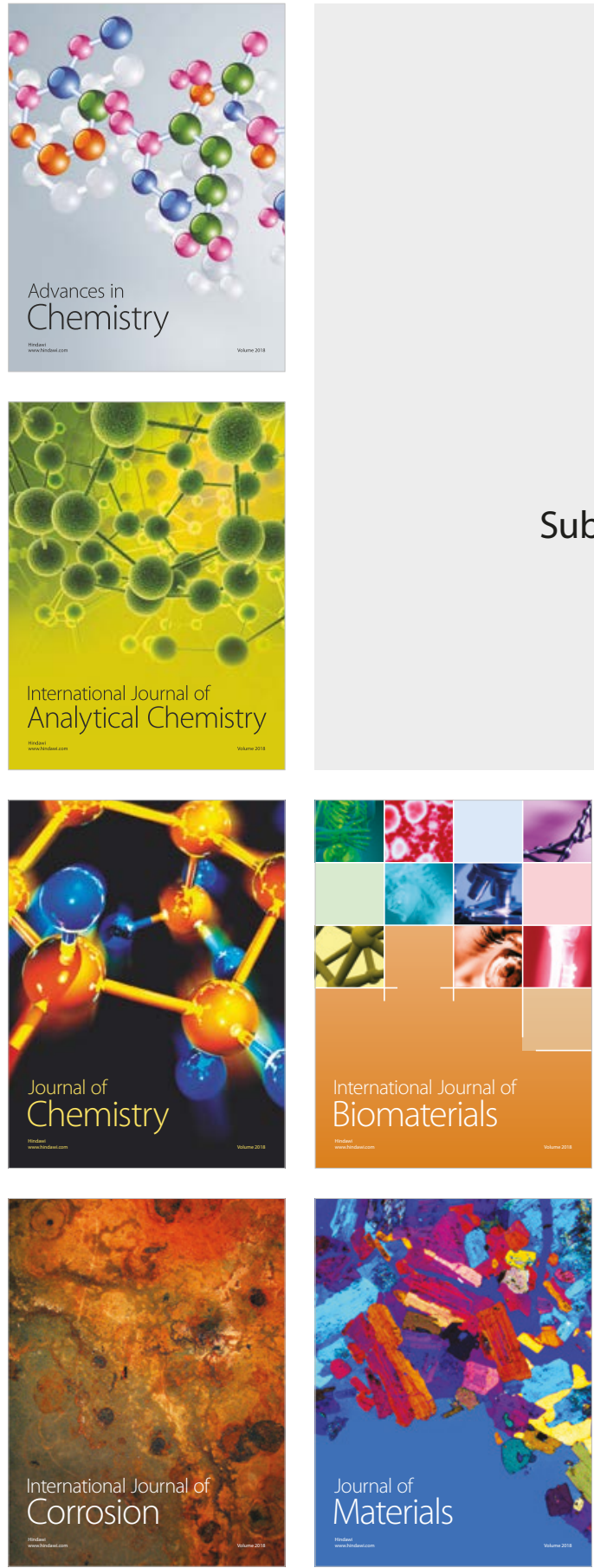

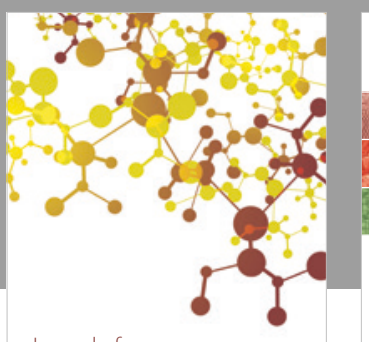

Journal of

Applied Chemistry
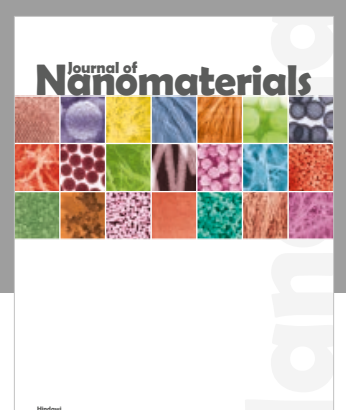

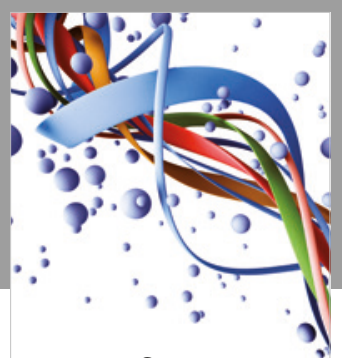

Scientifica

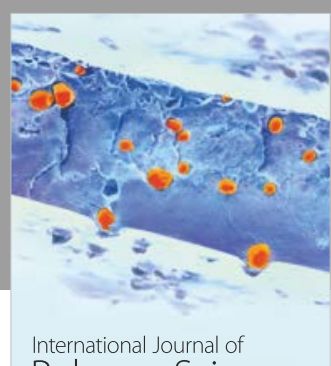

Polymer Science

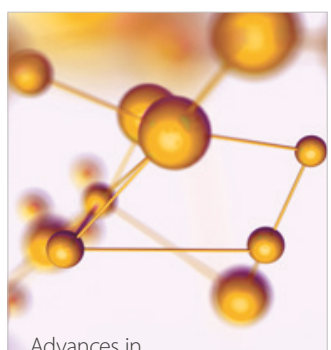

Physical Chemistry
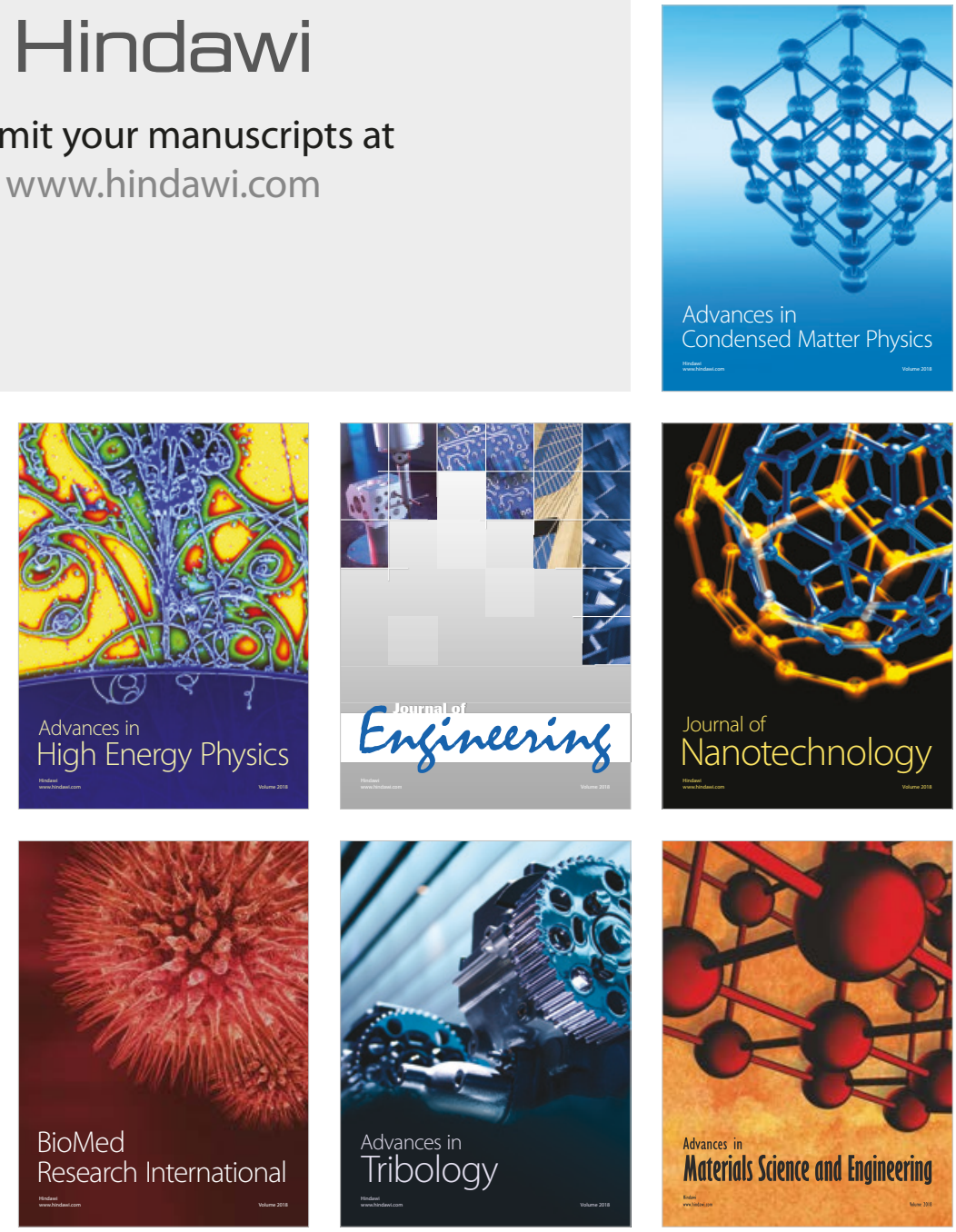